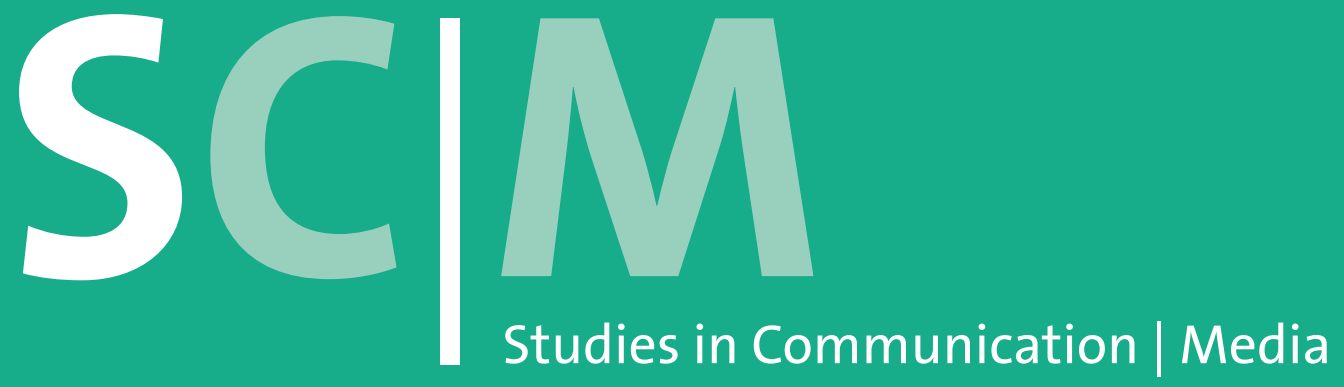

\title{
RESEARCH-IN-BRIEF
}

\section{How Visible is Communication Studies? \\ Press Coverage of the Discipline in Three German-Language Quality Newspapers}

\begin{abstract}
Wie sichtbar ist die Kommunikationswissenschaft?
Die Presseberichterstattung über die Disziplin in drei deutschsprachigen Qualitätszeitungen
\end{abstract}

Cornelia Brantner \& Brigitte Huber 
Cornelia Brantner, Department of Communication, University of Vienna Institut für Publizistik- und Kommunikationswissenschaft, Universität Wien, Währinger Straße 29, A-109o Wien; e-mail: cornelia.brantner(at)univie.ac.at

Brigitte Huber, Department of Communication, University of Vienna Institut für Publizistik- und Kommunikationswissenschaft, Universität Wien, Währinger Straße 29, A-1090 Wien; e-mail: brigitte.huber(at)univie.ac.at 


\title{
How Visible is Communication Studies? Press Coverage of the Discipline in Three German-Language Quality Newspapers
}

\author{
Wie sichtbar ist die Kommunikationswissenschaft? \\ Die Presseberichterstattung über die Disziplin in drei \\ deutschsprachigen Qualitätszeitungen
}

\section{Cornelia Brantner \& Brigitte Huber}

\begin{abstract}
Stimulated by public debates on the media presence of communication studies, the current study is the first to examine the media coverage of the discipline. In a quantitative content analysis, the coverage of three German-language quality newspapers in both 1999 and 2009 was analyzed in order to compare news reporting on the discipline's findings and on experts' statements. Overall, communication studies was rarely covered in the science section, but was instead reported on by media journalists and chronicle, feature, political and cultural journalists. In their coverage, the journalists show high interest in research and statements on media politics, system and structures, on journalists themselves and on political communication. The findings indicate that communication studies are increasingly used as an additional element in news reporting, particularly in the form of expert statements. Moreover, there is evidence that the initiative of scholars and their willingness to act as experts are the more decisive factors for media coverage than the journalism culture.
\end{abstract}

Keywords: science coverage, content analysis, communication studies, communication science, experts

Zusammenfassung: Ausgangspunkt der vorliegenden Studie ist die Debatte über die Medienöffentlichkeit der Kommunikationswissenschaft. Bislang liegen noch keine empirischen Daten zur Berichterstattung über das Fach vor. Hier schließt der Beitrag an und liefert erstmals entsprechende Daten einer Inhaltsanalyse deutschsprachiger Qualitätszeitungen der Jahre 1999 und 2009. Die Resultate zeigen, dass über Kommunikationswissenschaft kaum im Wissenschaftsressort berichtet wird. Der höchste Anteil von Artikeln fand sich im Medienressort; aber auch Chronik-, Feuilleton, Politik- und KulturjournalistInnen berichten darüber. Die Berichterstattung konzentriert sich auf Studien und ExpertInnenstatements aus den Bereichen Medienpolitik, Mediensystem und -strukturen, Kommunikatorforschung (v. a. JournalistInnen) und politische Kommunikation. Es zeigt sich darüber hinaus, dass kommunikationswissenschaftliches Wissen zunehmend als Zusatzelement in der Berichterstattung Verwendung findet und zwar vorwiegend in Form von ExpertInnenstatements. Des Weiteren scheint die Bereitschaft von Kommunikationswissen-schaftlerInnen als ExpertInnen zu fungieren und die Initiative Einzelner in stärkerem Maße bestimmend für die Berichterstattung zu sein als die journalistische Kultur.

Schlagwörter: Wissenschaftsberichterstattung, Inhaltsanalyse, Kommunikationswissenschaft, Experten 
Over the last decades, the practical importance and the societal relevance of communication studies have been recurring subjects in public debate. In 1996, in the weekly Die Zeit, Silbermann imputed "quirky pomposity" and "reality blind uselessness" to German communication studies, a reproach that did not remain uncontested. Russ-Mohl (1997) countered that the discipline was not actually inefficient, but its central problem was rather "that these performances obviously are not even noticed adequately by peers, let alone media practices or the general public". He blamed this problem on the underdeveloped communication ability of the discipline as well as on the journalists' lack of interest in communication research. Saxer (1997) spoke of a "precarious mass media public" of the social sciences in general and joined in the "lament of social scientists over their scarce media presence" (Weßler, 1997, p. 117). However, in the "media society", a lack of media attention is deemed problematic because the low media presence of a discipline could indicate its low societal relevance (Peters et al., 2008; Rademacher, 2011).

As the question on the visibility of our discipline in the public sphere remains unresolved, the objectives of this article were to provide empirical evidence for the media presence of research and scholars in German-language quality newspapers and to discuss the journalistic coverage of the discipline against the background of medialization (Peters, 2012; Peters et al., 2008; Weingart, 2012). On a macro level, the "medialization of science" refers to the interrelations between science and media (Weingart, 2010, p. $17)$ and to two simultaneous process- es: (1) media attention for scientific issues increases, and (2) as science faces the growing pressure of legitimation, it adapts to media criteria by means of public communication (Peters, 2012). Hence, communicating to the public becomes more and more important for scientists and scientific institutions (Peters et al., 2008; Schäfer, 2011).

\section{Literature Review and Research Questions}

There is a lack of research on the media's coverage of social sciences, in general, and communication studies, in particular. According to Schäfer's (2012, p. 655) meta-analysis of studies on science coverage, $93 \%$ of the analyzed disciplines are natural sciences, and only $6 \%$ of the studies observe social science coverage. Thus, there are only a few, mainly older, studies that explicitly look at the press coverage of social sciences (e.g., Evans, 1995; Fenton et al., 1998; Hömberg, 1981; Jarren \& Weßler, 1996; Weßler, 1997; Weiss \& Singer, 1988), but hardly any research exists that takes communication studies into account (except Böhme-Dürr, 1992; Hohlfeld, 2003; Krüger \& Müller-Sachse, 1998; but the coverage of our discipline is not their main focus). Moreover, some of the works on media journalism consider media research reporting as a subarea of media journalism (e.g., Beuthner, 2005; Malik, 2004) but do not provide empirical data on the coverage of communication studies.

Hence, our study is rather exploratory, and we formulate broad research questions based on the following literature review. In addition, we address the question whether the media cover- 
age of the discipline shows signs of medialization. Therefore, we apply two of the three indicators proposed by Schäfer (2009): extensiveness and increasing controversy. Extensiveness refers to the overall increase of science coverage, whereas controversy signifies the increasing evaluation of science and refers to its growing critical evaluation. ${ }^{1}$ Furthermore, we investigate if the coverage of the discipline can be traced back and linked to intensified agenda-building efforts (Schäfer, 2011), particularly improving PR work.

Overall, empirical studies investigating science coverage in general demonstrate that social sciences are less frequently reported than natural sciences (e.g., Böhme-Dürr, 1992; Göpfert \& Schanne, 1998; Kaltenbrunner et al., 2006). Yet in the longitudinal perspective, their coverage has increased (Göpfert \& Schanne, 1998), particularly if social science findings reported as ancillary items are taken into account (Weiss \& Singer, 1988) or in respect to experts functioning as pundits (Albaek et al., 2003). Accordingly, in our analysis, we distinguish between the coverage of studies and the citation of pundits' statements (e.g., Fenton et al., 1998; Jarren \& Weßler, 1996). We are particularly interested in the question whether our findings match those by Albaek et al. (2003), who found social scientists in Danish newspapers to be covered increasingly and to serve predominantly as expert commenta-

1 Our conceptualization does not allow for an adequate gauging of the third dimension that Schäfer (2009) proposes (pluralization). It refers to the increasing actor and content diversity, and can only be observed within a design focusing on the coverage of specific issues. tors on several issues, whereas only few references are made to their explicit research results.

RQ1: How do newspapers cover communication studies in terms of "coverage modes"? (a) Has the amount and nature of the coverage of communication studies changed from 1999 to 2009? (b) Is there a difference between the three investigated quality newspapers?

RQ2: What differences can be detected between the coverage of communication research and the expert statements in the coverage, and are there differences between the years?

Research has shown that social sciences mainly appear outside the science sections (e.g., Goepfert \& Schanne, 1998; Kaltenbrunner et al., 2006), and many journalists reporting science news in these sections are assumed to "not recognize that they do science journalism" (Wormer, 2009). Moreover, "media research journalism" is deemed a subarea of media journalism (e.g., Beuthner, 2005; Malik, 2004). Accordingly, we expect communication studies mainly to be covered outside the science sections and, in particular, in media sections.

RQ3: Which sections are dominant in covering the discipline, and can it be confirmed that communication studies is rarely reported on in science sections?

Furthermore, the triggers for coverage - in particular, the agenda-building efforts by scientists and science institutions - are of interest.

RQ4: What triggers is the coverage based on, and are the scientific triggers increasing over time? 
Findings show that editorial comments on science are relatively rare, with most of them being positive (e.g., Elmer et al. 2008; Fenton et al., 1998; Göpfert \& Schanne, 1998). Medialization within the dimension "controversy", however, is expected to yield an increase in the amount of evaluations as well as of critical evaluations.

RQ5: How do the media evaluate scientific knowledge of the discipline and/or the discipline as a whole? Can we observe increasing controversy in the coverage from 1999 to 2009?

As there are hardly any comparable empirical results on our discipline and on the covered research topics and areas, we broadly ask the following:

RQ6: What are (a) the media types the covered studies and statements deal with and (b) the research fields and topics that garner media attention?

\section{Methods}

In a quantitative content analysis, we analyzed all articles dealing with communication studies' findings and/or experts (from universities and other noncommercial research institutions) published in 1999 or 2009 in the Süddeutsche Zeitung (Germany), Neue Zürcher Zeitung (NZZ, Switzerland), and Der Standard (Austria). The main focus of interest was set on the structure and intensity of the newspapers' reporting rather than on the crosscountry comparison. The leading national newspapers were chosen because they signify both excellent and responsible quality journalism (Blum,
2011) and are expected to provide the most intense coverage of communication studies. Obviously, the examination of only one newspaper per country might endanger creating a biased view insofar as a single proxy might not be representative for the whole spectrum of a country's quality media. Therefore, we strongly suggest testing our findings in the scope of larger-scale studies. Yet the present study does not focus on a comparison of countries but serves as an exploratory study, being the first to question how Germanlanguage newspapers cover the discipline.

The sample comprises two dates of measurement as it was of interest whether the media coverage has changed since Silbermann (1996) and Russ-Mohl (1997) made their diagnoses. We selected 1999 instead of 1996 for practical reasons, as it was the first year in which all three media were stored in the selected databases. As only two periods were analyzed, inferences about longitudinal trends are made with caution.

The methodological conception of the study as a quantitative content analysis only enabled us to observe manifest content. Hence, the latent scientific knowledge transfer and thus the implicit diffusion (Weßler, 1997) of communication studies content were not measurable in this study and thus remain subject to future research.

\section{Sample}

The data encompass a full inquiry of the newspapers in 1999 and 2009. For article collection, we used the data banks Wiso and Factiva, using the 
same 44 keywords $^{2}$ for all observed media. The coding process was conducted for every article in which communication studies appeared explicitly, regardless of whether it was the main topic or an ancillary item.

\section{Variables Examined}

Coverage modes: To assess the different modes of media coverage of the discipline, we coded the articles into seven categories derived from the science's share, genre, main topic, and knowledge type, for example, "communication science journalism" (for the categories, see Table 1).

Science share: If more than half of the article dealt with communication studies, it was coded as the "main topic." The coding scheme further distinguished between "big" (more than a third of the article's share) and "small" ancillary items (less than a third). As minor references also contribute to the

2 kommunikationswiss, medienwissens, publizistik, journalistik, kommunikationsforsch, medienforsch, medienpsych, kommunikationspsych, medienprofe, kommunikationsprofe, medienexpert, kommunikationsexpert, medienökonom, mediendoz, kommunikationsoziolog, mediensoziolog, mediengeschicht, medienanalys, medienpädagog, kommunikationstheor, medientheor, wissenschaftskommunik, wissenschaftsjournalis, wissenschaftsberichterst, Journalistenschul, Journalistenausbild, Journalismusausbild, Medienausbild, professor AND kommunikation, professor AND medien, professor AND journalis, journalis AND wissenschaft, medien AND wissenschaft, journalis AND forsch, medien AND forsch, kommunikation AND forsch, kommunikation AND wissenschaft, soziolog AND medien, soziolog AND kommunikation, studie AND medien, studie AND kommunikation, studie AND journalis, untersuch AND medien, untersuch AND kommunikation, untersuch AND journalis (the fulltext search was carried out with truncation). visibility of the discipline, they were coded as well (e.g., articles mentioning communication studies incidentally or fleetingly but containing at least actors' names or institutions).

Sections, genres, and main topics: The articles were categorized by the newspapers' section in which they appeared and by their journalistic genre. The main topics of the articles (beside communication studies) were coded into 15 categories (e.g., media, political, and economic issues).

If an article contained knowledge elements (communication studies research or experts' statements), the following variables were coded additionally. For each article, only one scientific knowledge element was coded in detail.

Knowledge type: It was assigned to which category ("research" or "expert statement") the element belongs.

Triggers: It was coded if the trigger for the coverage of communication studies was scientific (e.g., launch/publication of results, press releases), partly scientific (e.g., discussions with participating scholars), or nonscientific.

Evaluations: Any positive, ambivalent, or negative evaluation of the study or the expert was coded, as well as who (e.g., journalist, guest editor) evaluated what (credibility, quality, comprehensiveness, and independence); multicoding was possible. Furthermore, it was analyzed if communication studies as a whole was the subject of judgments.

Media type: Each knowledge type was coded in terms of the media subject it was concerned with, categorizing if the article dealt with print, print and TV, broadcasting (TV and/or radio), online, print and online media, media or journalism in general, and 
other media (e.g., video games) or had no direct relation to media or journalism.

Research fields and topics: In accordance with Lasswell's formula and the systematization of the process of public communication by Bentele et al. (2003), the knowledge elements were categorized within the following five research fields: (1) media analysis, (2) communicator, (3) media content, (4) audience and media use, and (5) media effect research. ${ }^{3}$ In addition to that, the subtopics gaining media attention within the research fields were coded (see Table 4).

Two coders coded the same $9 \%$ of the sample to establish intercoder reliability. Reliability was checked by means of the percentage of agreement, yielding sufficient scores ranging from $100 \%$ to $76 \%$ (for evaluation).

\section{Results}

\section{Amount and Coverage Modes (RQ1)}

In sum, 587 articles dealing with communication studies were coded. Thus, on average, every third day, an article covering the discipline was published in each newspaper. Our results show a variety of ways journalists report on the discipline. Overall, seven different modes of coverage were identified (see Table 1).

The first category, "communication science journalism”, contains all articles dealing with communication studies or researchers as the main item $(19.8 \%)$. If it was not the main topic but instead the article reported a me-

3 It has to be noted that although expert statements did not refer to research results explicitly, the field of research referred to was coded. dia issue and thereby incorporated communication studies as a subissue or just referred to it, the article was assigned to the second category, that is, "media journalism including...". This applies to more than one in every four articles $(27.9 \%)$. The third category, the articles on other topics (mainly societal or political), included studies $(2 \%)$ and experts $(3.9 \%)$ of the discipline or referred to it $(5.8 \%)$. The fourth category, "guest editorials" of communication scientists, represents $10.2 \%$ of the reports. It was mainly the NZZ that gave communication scholars a platform for direct knowledge transfer. In particular, this may be attributed to the fact that in the NZZ, scholars (e.g., Russ-Mohl) write guest editorials on a regular basis. A further $3.4 \%$ of the articles stem from other guest editors citing experts from the discipline (category five). The sixth category, "training and study", consists of articles giving information about the study of communication or associated disciplines as well as on professional training within the course of studies $(10.4 \%)$ or similar references $(8.3 \%)$. Finally, the seventh category includes short notices on scholars, primarily announcements and personnel updates $(8.2 \%)$.

\section{Differences between years and among media (RQ1a and RQ1b)}

The "extensiveness" of the reporting, that is, whether the discipline's representation increased in the analyzed newspapers from 1999 to 2009, was examined. Altogether, the amount of coverage rose by $12.7 \%$ between the two analyzed years, from 276 to 311 articles. Although the overall visibility 
Table 1: Coverage Modes per Year and per Media

\begin{tabular}{|c|c|c|c|c|c|c|}
\hline \multirow[b]{2}{*}{ Coverage mode } & \multirow[b]{2}{*}{$\begin{array}{c}\text { Total } \\
\%\end{array}$} & \multicolumn{2}{|c|}{ Year } & \multicolumn{3}{|c|}{ Media } \\
\hline & & $\begin{array}{c}1999 \\
\%\end{array}$ & $\begin{array}{c}2009 \\
\%\end{array}$ & $\begin{array}{c}\text { Standard } \\
\%\end{array}$ & $\begin{array}{c}S D Z \\
\%\end{array}$ & $\begin{array}{c}N Z Z \\
\%\end{array}$ \\
\hline 1. Communication science journalism & 19.8 & 21.7 & 18.0 & 19.6 & 14.1 & 25.0 \\
\hline \multicolumn{7}{|l|}{ 2. Media journalism including } \\
\hline research results & 5.3 & 5.8 & 4.8 & 1.7 & 6.8 & 6.9 \\
\hline scientific experts & 16.0 & 13.0 & 18.6 & 14.0 & 24.0 & 10.6 \\
\hline references & 6.6 & 6.5 & 6.8 & 4.5 & 7.8 & 7.4 \\
\hline \multicolumn{7}{|l|}{ 3. Other topics including } \\
\hline communication research & 2.0 & 0.7 & 3.2 & 1.1 & 2.1 & 2.8 \\
\hline scientific experts & 3.9 & 2.9 & 4.8 & 5.6 & 4.7 & 1.9 \\
\hline references & 5.8 & 7.2 & 4.5 & 6.1 & 5.2 & 6.0 \\
\hline \multicolumn{7}{|l|}{ 4. Guest editorials } \\
\hline communication scientists as experts & 6.8 & 8.7 & 5.1 & 6.7 & 2.6 & 10.6 \\
\hline $\begin{array}{l}\text { communication scientists incl. re- } \\
\text { search }\end{array}$ & 3.4 & 2.5 & 4.2 & 2.2 & 0.0 & 7.4 \\
\hline $\begin{array}{l}\text { 5. Other guest commentators citing } \\
\text { communication scholars }\end{array}$ & 3.4 & 5.4 & 1.6 & 1.1 & 3.1 & 5.6 \\
\hline \multicolumn{7}{|l|}{ 6. Training and Study } \\
\hline main topic or ancillary item & 10.4 & 13.4 & 7.7 & 17.3 & 9.9 & 5.1 \\
\hline references & 8.3 & 7.2 & 9.3 & 7.3 & 10.9 & 6.9 \\
\hline $\begin{array}{l}\text { 7. Event announcements, prices, and } \\
\text { personnel updates (short notices) }\end{array}$ & 8.2 & 4.7 & 11.3 & 12.8 & 8.9 & 3.7 \\
\hline$\%$ of total (column) & $99.9 *$ & $99.7 *$ & $99.9 *$ & 100.0 & $100.1 *$ & $99.9^{*}$ \\
\hline $\begin{array}{l}\text { Total articles containing at least } \\
\text { references }(\mathrm{N})\end{array}$ & 587 & 276 & 311 & $179^{a}$ & $192^{\mathrm{a}}$ & $216^{a}$ \\
\hline$\%$ of total (row) & 100.0 & 47.0 & 53.0 & 30.5 & 32.7 & 36.8 \\
\hline Knowledge elements $(\mathrm{N})$ & 356 & 168 & 188 & 96 & 105 & 155 \\
\hline
\end{tabular}

Note. For media/coverage mode: $\chi^{2}(24)=91.103, p<.05$; for media/year: $\chi^{2}(12)=35.017, p<.05 ;{ }^{*}$ rounding error; ${ }^{a}$ Der Standard published 76 articles on communication studies in the year 1999 and 103 in the year 2009, the Süddeutsche Zeitung 83 in the year 1999 and 109 in the year 2009, and the NZZ 117 in the year 1999 and 99 in the year 2009.

of the discipline increased, our results do not reveal a consistent picture on the changing amount of coverage. While the number of articles in the NZZ decreased slightly, ${ }^{4}$ the number of articles in the other two newspapers increased. Overall, the NZZ published the most articles and outruns Der Standard and Süddeutsche Zeitung in

4 See note 6 . terms of "communication science journalism" in the narrower sense.

Knowledge Types: Research and Experts (RQ2)

Up to this point, we considered all 587 articles dealing with the discipline in a variety of ways. In this section, we focus on those articles containing knowledge of the discipline. In sum, 356 arti- 
cles with knowledge elements were identified (boldfaced data in Table 1). These elements were further coded into "research" or "expert statement" (see Table 2).

Journalists cover both research $(46.9 \%)$ and expert statements $(48.9 \%)$ with about the same frequency. The latter category comprises all statements where scholars functioned as pundits commenting on issues and topics without referring explicitly to current research. If an article reported research results, these tended to appear as the main item $(75.4 \%)$. The reverse picture emerges when looking at the expert statements, with $59.8 \%$ of them being used as ancillary item in the coverage.

The increase in the overall covered knowledge elements may be attributed to the increase in the coverage of pundit statements in 2009 (from 77 to 97), whereas the coverage of research remained almost at the same level (81 and 86). Thus, our results confirm to the findings of Albaek et al. (2003, p. 944f), who stated that social science scholars are increasingly covered by media. We also found, similar to the study of Albaek et al. (2003, p. 945), that communication scholars are mainly commenting on several issues without referring to research results. Taken together, the current study found $239^{5}$ articles in which they had a say, but only $27 \%$ of their statements involved research findings.

\section{Sections ( $\left.R Q_{3}\right)$}

As expected, very few $(4.2 \%)$ of the articles were found in science sections. Most articles were published in the media sections $(42.4 \%)$ or with a share of $53.3 \%$ in other sections, particularly in chronicle $(9.8 \%)$, political $(8.4 \%)$, feature $(9.8 \%)$, or culture

5 In sum, $65(39 \%)$ of the 167 reports on research findings included comments from scientific researchers, but as findings were the main focus of these items, they were classified as "research" articles. Taken together, we found 239 articles covering expert statements (174 of which were without references to research findings plus the 65 on research findings that included scholars' statements).

Table 2: Knowledge Types per Media and Science Share

\begin{tabular}{|c|c|c|c|c|c|c|c|}
\hline \multirow[b]{3}{*}{ Knowledge type } & \multirow{3}{*}{$\begin{array}{c}\% \\
\text { of } \\
\text { total }\end{array}$} & \multicolumn{3}{|c|}{ Media } & \multicolumn{3}{|c|}{ Science share } \\
\hline & & Standard & SDZ & NZZ & $\begin{array}{c}\text { Main } \\
\text { item }\end{array}$ & $\begin{array}{c}\text { Big } \\
\text { ancillary }\end{array}$ & $\begin{array}{c}\text { Small } \\
\text { ancillary }\end{array}$ \\
\hline & & \multicolumn{3}{|c|}{$\%$ of articles within media } & \multicolumn{3}{|c|}{$\%$ within knowledge type } \\
\hline Research $(\mathrm{N}=167)$ & 46.9 & 40.6 & 35.2 & 58.7 & 75.4 & 9.0 & 15.6 \\
\hline $\begin{array}{l}\text { Expert statements } \\
(\mathrm{N}=174)\end{array}$ & 48.9 & 57.3 & 57.1 & 38.1 & 40.2 & 14.4 & 45.4 \\
\hline Other forms* $(\mathrm{N}=15)$ & 4.2 & 2.1 & 7.6 & 3.2 & 26.7 & 6.7 & 66.7 \\
\hline$\%$ column & 100.0 & 100.0 & $99.9 * *$ & 100.0 & & & \\
\hline$\%$ of total $\mathrm{N}=356$ (row) & 100.0 & & & & 56.2 & 11.5 & 32.3 \\
\hline Total N (row) & 356 & 96 & 105 & 155 & & & \\
\hline
\end{tabular}

Note. For knowledge types/media: $\chi^{2}(4)=19,307, \quad p<.05$; for knowledge types/science share: $\chi^{2}(4)=52.911, p<.05$; ${ }^{*}$ other forms of knowledge types e.g. contain references to a discipline's theory without covering research or recent expert statements; * rounding error. 
$(5.3 \%)$ sections. $^{6}$ Thus, the current study confirms what several studies already found (e.g., Kaltenbrunner et al., 2006; Weßler, 1997), that is, social sciences are deemed "outside the realm of accepted science journalism" (Elmer et al., 2008, p. 881).

\section{Triggers (RQ4)}

Table 3 illustrates that the most common triggers for reporting on the discipline were nonscientific in nature $(58.4 \%) .34 .2 \%$ of the coverage relied on scientific triggers, but scientific journals as sources were mentioned in only five cases. Although scientific journals are important sources for science journalists (Elmer et al., 2008), journalists writing about the discipline largely ignore the discipline's journals.

6 The decline of the overall coverage in the $\mathrm{NZZ}$ might be at least partly attributed to the fact that it diminished its media section in 2007 (Straub \& Schönhagen, 2007). Indeed, in 2009 we found fewer articles (33) in the media section than in 1999 (39), but it's noteworthy that the decline was even higher in the domestic-politics section (-9).
The concept of the medialization of science suggests that scientists and science institutions have increased their agenda-building efforts (Peters et al., 2008; Schäfer, 2011). Still, our findings indicate that these efforts were not reflected in the media. Contrary to the expectation, the share of scientific triggers slightly decreased. However, it must be pointed out that we were not able to determine scientific triggers if they were not indicated within the article itself. Additional input-output analyses and interviews with journalists and scholars are thus needed to satisfactorily examine this aspect.

\section{Evaluations ( $\left.R Q_{5}\right)$}

An evaluation of a study or an expert was identified in $97(27 \%)$ of the total 356 articles. Around $54 \%$ of these comments were positive, only $15 \%$ were negative, the rest $(31 \%)$ were ambivalent. In comparison to the findings of Fenton et al. (1998, p. 31), the present study found a slightly higher share of evaluations ( $27 \%$ vs. $20 \%$ ) on the one hand, but less critical comments $(15 \%$ vs. $40 \%)$ on the other.

\section{Table 3: Triggers for Reporting Communication Studies}

\begin{tabular}{|c|c|c|c|c|c|}
\hline \multirow[b]{2}{*}{ Triggers } & \multirow[b]{2}{*}{$\begin{array}{c}\text { Total } \\
(\%)\end{array}$} & \multicolumn{2}{|c|}{ Science share } & \multicolumn{2}{|c|}{ Year } \\
\hline & & $\begin{array}{l}\text { Ancillary } \\
\text { issue }(\%)\end{array}$ & $\begin{array}{c}\text { Main } \\
\text { issue }(\%)\end{array}$ & $\begin{array}{l}1999 \\
(\%)\end{array}$ & $\begin{array}{c}2009 \\
(\%)\end{array}$ \\
\hline Non scientific triggers & 58.4 & 80.8 & 41.0 & 51.8 & 64.4 \\
\hline Scientific triggers: & 34.2 & 8.9 & 54.0 & 37.5 & 31.4 \\
\hline Launch/publication of results & 27.5 & 1.9 & 47.5 & & \\
\hline Press conference, press release from scientists & 2.8 & 3.2 & 2.5 & & \\
\hline Scientific news agency report & 0.8 & 0.6 & 1.0 & & \\
\hline Scientific conferences & 3.1 & 3.2 & 3.0 & & \\
\hline $\begin{array}{l}\text { Partly scientific triggers: Other conferences } \\
\text { (e.g. discussions with participants from the } \\
\text { discipline) }\end{array}$ & 7.3 & 10.3 & 5.0 & 10.7 & 4.3 \\
\hline Total (N) & 356 & 156 & 200 & 168 & 188 \\
\hline
\end{tabular}

Note. For ancillary or main issue/triggers: $\chi^{2}(5)=93.474, p<.05$; for year/triggers: $\chi^{2}(2)=8.438, p<.05$ 
In the present study, most of the evaluations dealt with the quality of scientific knowledge $(n=75)$. The credibility of scientific knowledge was the second most frequently evaluated $(n=55)$, whereas both the comprehensiveness $(n=9)$ and the independence $(n=6)$ of scientific knowledge were seldom the subject of commentary.

Most articles with evaluations were found in the NZZ (56\%); Süddeutsche Zeitung and Der Standard contained $30 \%$ and $14 \%$ of the evaluations, respectively. Almost half of the 15 negative evaluations were made in the Süddeutsche Zeitung. Two-thirds of all evaluations stem from journalists and were mainly made within opinion-oriented genres.

However, it could be argued that a lack of critical assessment and additional information hinders audiences from drawing their own conclusions
(Elmer et al., 2008; Weßler, 1997). Overall, our study provides no evidence regarding the "increasing controversy" dimension of medialization. On the contrary, $54 \%$ of the evaluations were found in 1999. Thus, neither the total amount of evaluations nor the ambivalent and critical evaluations have increased.

In responding to negative reactions from journalists to a study investigating the current state and quality of Swiss media, Wyss (2011) claimed that for public debates in democracies, a type of media journalism is needed that does not react with "science bashing". However, we found only 31 articles containing evaluations of the discipline, and only in three articles, all found in the Süddeutsche Zeitung, the field itself was "bashed" by journalists.

\section{Figure 1: Covered Media Types of the Reported Studies and Statements}

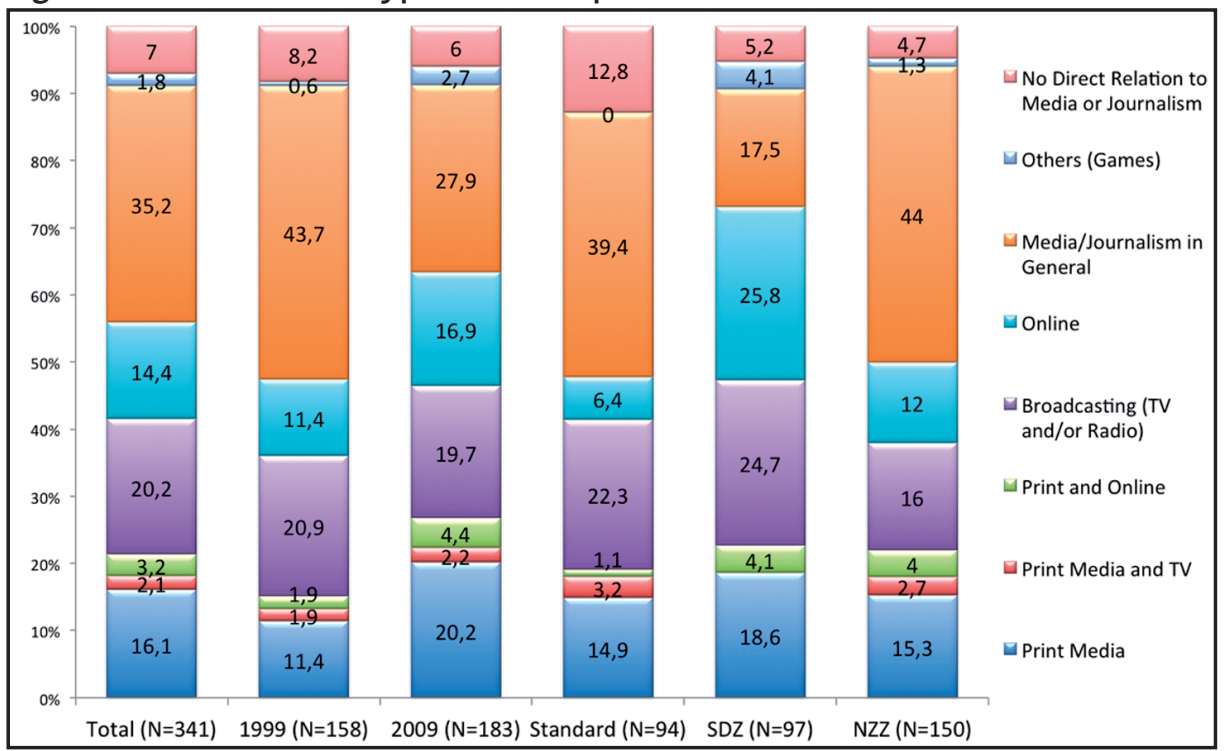

Note. For media types/year: $\chi^{2}(7)=6.347, p<.05$, for media types $/$ media: $\chi^{2}(14)=44.626, p<.05$ 
Figure 2: Process Systematic of Public communication: Covered Resea

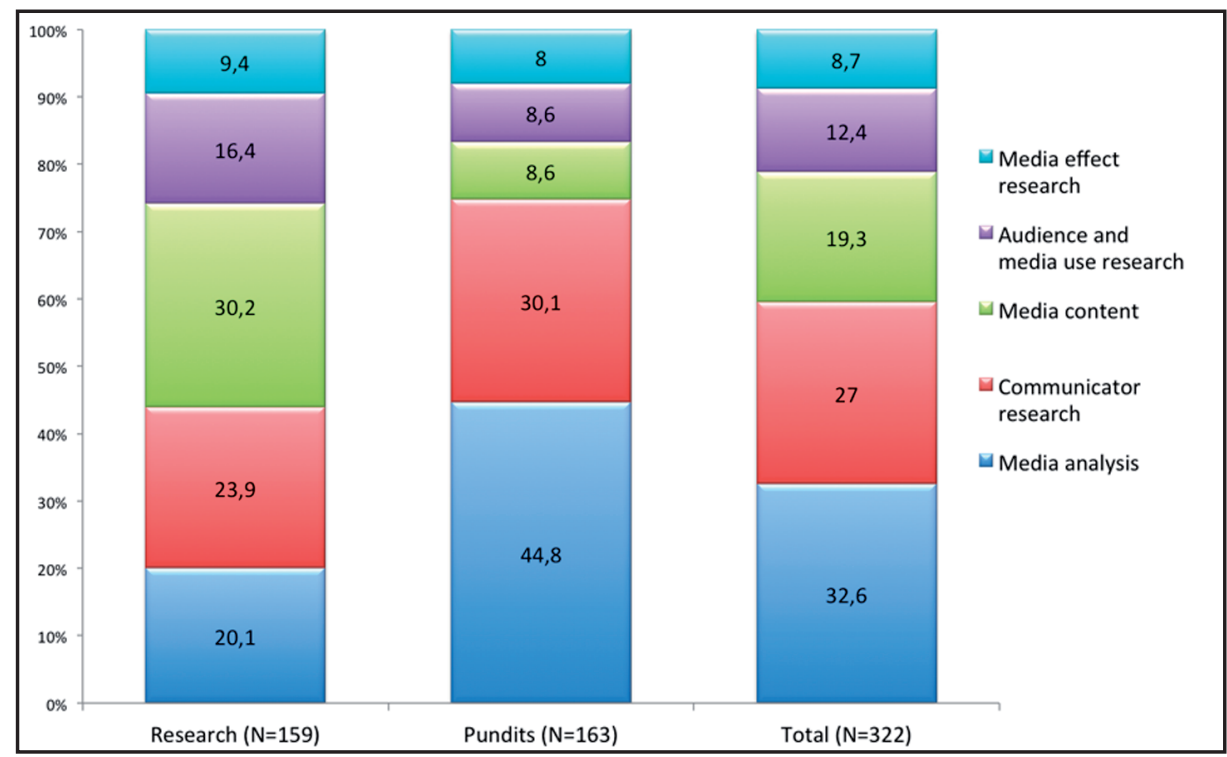

Note. For research fields/knowledge type: $\chi^{2}(4)=39.745, p<.05$

\section{Media Types (RQ6a)}

Figure 1 shows that research and statements on the media or journalism in general were the subjects of $35.2 \%$ of the knowledge elements. The observed newspapers also had a high interest in findings and statements on print media $(21.4 \%$, thereof $16.1 \%$ on print media alone, $2.1 \%$ on print media and TV, and $3.2 \%$ on print and online media). The newspapers were interested in scientific knowledge on broadcasting to almost the same degree $(20.2 \%)$.

Knowledge on media and journalism in general was less often reported in $2009(27.9 \%)$ than that in 1999 $(43.7 \%)$. Not surprisingly, research and statements on print media $(11.4 \%$ to $20.2 \%$ ) on the relationship, influence, and disparity between traditional and online media $(1.9 \%$ to $4.4 \%)$ and on online media ( $11.4 \%$ to $16.9 \%)$ attained increased attention in 2009.
Among the three newspapers, selfmonitoring and potential self-reflection reached almost the same level, as studies and statements on print media had a similar share in the papers.

\section{Research Fields and Topics (RQ6b)}

In the interest of clarity, Figure 2 contains only those 322 knowledge elements that could be classified under the five research fields mentioned before. ${ }^{7}$

Findings and statements concerning media analysis were reported the most frequently $(32.6 \%)$, followed by communicator analysis $(27.0 \%)$ and media content $(19.3 \%)$. Newspapers showed less interest in the research fields audience and media use $(12.4 \%)$ and media effects $(8.7 \%)$.

719 cases could not be assigned to any category; most of them were not about public communication. 
Table 4: Covered Topics Within the Research Fields $(\mathrm{N}=322)$

\begin{tabular}{|c|c|c|c|}
\hline Research fields & $\begin{array}{c}\% \text { of } \\
\text { total } \\
(\mathrm{N}=322)\end{array}$ & Topics, \% within research field & \\
\hline Media analysis & 32.6 & $\begin{array}{r}\text { Media politics and regulation } \\
\text { Media systems and media structures } \\
\text { Media economy } \\
\text { History of media } \\
\text { Media culture } \\
\text { Media law } \\
\text { Others }\end{array}$ & $\begin{array}{r}33 \\
29 \\
16 \\
9 \\
6 \\
4 \\
3\end{array}$ \\
\hline Communicator research & 27.0 & $\begin{array}{r}\text { Journalists } \\
\text { Politicians, PR people } \\
\text { Several communicators }\end{array}$ & $\begin{array}{l}60 \\
19 \\
21\end{array}$ \\
\hline Media content & 19.3 & $\begin{array}{r}\text { Political coverage in general } \\
\text { Political coverage of a specific subject } \\
\text { Election coverage } \\
\text { Foreign news coverage } \\
\text { Social media from politicians } \\
\text { Ethnic minorities, xenophobia, rightwing radicalism } \\
\text { War, conflicts, violence, crime } \\
\text { Risk, health, science coverage } \\
\text { News coverage (in general or other specific topics) } \\
\text { Media content in general } \\
\text { Social media content } \\
\text { Economy } \\
\text { Entertainment } \\
\text { Others } \\
\text { Advertising }\end{array}$ & $\begin{array}{r}6 \\
8 \\
8 \\
6 \\
3 \\
15 \\
10 \\
8 \\
10 \\
11 \\
3 \\
3 \\
3 \\
3 \\
2\end{array}$ \\
\hline $\begin{array}{l}\text { Audience and media } \\
\text { use research }\end{array}$ & 12.4 & $\begin{array}{r}\text { Media literacy, media use by social variables, } \\
\text { socialization } \\
\text { Functions and motives, uses and gratifications } \\
\text { Extent of media use } \\
\text { Evaluations (e.g. trust, credibility, quality) }\end{array}$ & $\begin{array}{r}35 \\
27.5 \\
20 \\
17.5\end{array}$ \\
\hline Media effect research & 8.7 & $\begin{array}{r}\text { Effects of political reporting } \\
\text { Effects of the internet on mental abilities } \\
\text { (e.g on concentration) } \\
\text { Effects of gaming (e.g. killer-games) } \\
\text { Effects on behavior } \\
\text { Effects of media coverage on knowledge and attitudes } \\
\text { Effects of advertising }\end{array}$ & $\begin{array}{r}18 \\
18 \\
7 \\
7\end{array}$ \\
\hline
\end{tabular}

Differences between the coverage of research and of experts can be noticed. While pundits received the greatest media attention when talking about topics in the field of media analysis $(44.8 \%)$, research reports relied on the findings of media content research to a high extent $(30.2 \%)$. Unsurprisingly, findings from audience research were covered more frequently $(16.4 \%)$ than expert statements in this field $(8.6 \%)$.

To sum up, the analysis of the research fields and topics (see Table 4) reveals that journalists show interest especially in the scientific knowledge on media politics, systems and struc- 
tures, journalists, and political communication.

\section{Conclusion}

This study has been the first to assess the coverage of communication studies in print media. It revealed relevant findings for both the discipline and our understanding of how the discipline is acknowledged by the media. Even though it is impossible to determine the right amount of coverage on communication studies, the analysis of the investigated newspapers revealed an article to be published every third day. Among these, the most frequent coverage was found in the NZZ, although its amount of reporting on the discipline decreased slightly from 1999 to 2009. In the Süddeutsche Zeitung and Der Standard, the number of articles increased over time. To summarize, the media coverage of communication studies has been extended, but only slightly. Our data did not support the assumption that a medialization of science would result in increasing controversy in the coverage. However, as already mentioned, the operationalization of controversy was limited to the measurement of the evaluation of studies and experts.

While there was no salient change between the investigated years regarding "communication science journalism" in the narrower sense, the newspapers used scientific knowledge as small ancillary items more frequently in 2009, and expert statements were especially used as additional elements in the coverage of other topics. This can be judged as an "indication for the penetration of social sciences into nonscientific contexts of coverage" (Jarren $\&$ Weßler, 1996, p. 11) because scien- tific knowledge is separated from its scientific context and re-contextualized by journalists. This finding is supported by the examination of the sections: communication studies is rarely mentioned in science sections but is generally covered by media journalists, followed by chronicle, feature, political, and culture journalists. In 2009, the journalists showed greater interest in scientific studies as well as in commentary on print media and the impact of online journalism on it. Hence, journalists demonstrate stronger self-monitoring and potential self-reflection. In doing so, they rely on scientific expertise. It may be argued that media research as a journalistic topic has a (at least slightly) growing influence on the media system "from the inside". ${ }^{8}$ However, as our study analyzed only two periods, an extension of the investigation period and longitudinal comparisons are needed to confirm this assumption.

The use of scientific knowledge as an ancillary element implies that it is not necessarily relied on for its new insights but instead is instrumentalized by journalists (Kepplinger et al., 1991). Indeed, surveys among journalists have shown that it is a common journalistic practice to determine the direction the expert statements should go and which position fits into a fixed journalistic story frame before conducting interviews with scientists (Albaek, 2011; Peters, 2008).

Some scholars (e.g., Meckel, 2011; Wyss, 2011) demand that their col-

8 Beuthner (2005, p. 88) deems a specific performance of "media research journalism" (one of four types of media journalism) to bring more contextuality and data into the medial self-observation and thus to promote the theory-praxis-integration. 
leagues improve their efforts, particularly their PR work, to enable a successful knowledge transfer that then underlines and enhances the societal relevance of the discipline. This study revealed that reporting on the occasion of scientific triggers has not increased. However, we contend that the initiative of scholars and their willingness to act as experts are the more decisive factors for media coverage than the journalism culture. Actually, only seven scholars account for $20 \%$ of the overall presence of scholars in the examined media. On the other hand, as Weischenberg stated (Dernbach, 2012, p. 240), it might diminish the reputation of the discipline if experts "publicly express their opinion on almost all issues". Moreover, it becomes obvious that our discipline is in a paradox situation, as it is involved in the processes of medialization itself but is at the same time bound to remain a scientific meta-observer of these very same processes.

The conceptualization of the current study did only allow for the examination of explicit knowledge transfer (Weßler, 1997). After all, many journalists have studied the discipline or related fields; thus, they may use knowledge stemming from their own university education without explicitly referring to sources. Moreover, the research subject of the social sciences and the commonsense knowledge of people overlap (Cassidy, 2008), as social science matters are "quite an everyday thing" (Saxer, 1997). Everyone is part of society and practices social behavior in everyday life, and in this regard (in contrast to natural science issues), lay theories also have a claim to legitimacy, as everybody may be termed an expert.

\section{References}

Albaek, E. (2011). The interaction between experts and journalists in news journalism. Journalism, 12(3), 335-349.

Albaek, E., Christiansen, P. M., \& Togeby, L. (2003). Experts in the mass media: Researchers as sources in Danish daily newspapers, 1961-2001. Journalism and Mass Communication Quarterly, 80(4), 937-948.

Bentele, G., Brosius, H.-B., \& Jarren, O. (Eds.). (2003). Öffentliche Kommunikation. Handbuch Kommunikationsund Medienwissenschaft. Wiesbaden: Westdeutscher Verlag.

Beuthner, M. (2005). Der „Über-Journalist" - Versuch einer Konturierung medienjournalistischer Kompetenzbereiche und Berichterstattungsfelder. In $\mathrm{M}$. Beuthner, \& A. Stephan (Eds.), Die Selbstbeobachtungsfalle. Grenzen und Grenzgänge des Medienjournalismus (pp. 75-92). Wiesbaden: VS-Verlag für Sozialwissenschaften

Blum, R. (2011). Leidende Leuchttürme. Über die Unentbehrlichkeit von Qualitätsmedien. In R. Blum, H. Bonfadelli, K. Imhof, \& O. Jarren (Eds.), Krise der Leuchttürme öffentlicher Kommunikation (pp. 7-14). Wiesbaden: VS-Verlag für Sozialwissenschaften

Böhme-Dürr, K. (1992). Social and natural sciences in German periodicals. Communications, 17(2), 167-176.

Cassidy, A. (2008). Communicating the social sciences. In M. Bucchi, \& B. Trench (Eds.), The handbook of public communication of science and technology (pp. 225-236). Routledge: London.

Dernbach, B. (2012). Siegfried Weischenberg. "Man ist bis zu einem gewissen Grad nützlicher Idiot.” In D. Dernbach (Ed.), Vom Elfenbeinturm ins Rampenlicht. Prominente Wissenschaftler in 
populären Massenmedien (pp. 237257). Wiesbaden: Springer VS.

Elmer, C., Badenschier, F., \& Wormer, H. (2008). Science for everybody? How the coverage of research issues in German newspapers has increased dramatically. Journalism \& Mass Communication Quarterly, 85(4), 878-893.

Evans, W. (1995). The mundane and the arcane: Prestige media coverage of social and natural science. Journalism \& Mass Communication Quarterly, 72(1), 168178.

Fenton, N., Bryman, A., Deacon, D., \& Birmingham, P. (1998). Mediating social science. London: Sage.

Göpfert, W., \& Schanne, M. (1998). Das Förderprogramm Wissenschaftsjournalismus der Robert Bosch Stiftung GmbH. Berlin/Zürich.

Hohlfeld, R. (2003). Journalismus und Medienforschung. Theorie, Empirie, Transfer. Konstanz: UVK.

Hömberg, W. (1981). Das verspätete Ressort. Die Situation des Wissenschaftsjournalismus. Konstanz: UVK.

Jarren, O., \& Weßler, H. (1996). Gesellschaftswissenschaften in der Medienöffentlichkeit. Darmstadt: SchaderStiftung.

Kaltenbrunner, A., Kraus, D., Leitner, J., \& Zimmermann, A. (2006). Weiterbildung für Wissenschaftsjournalisten. Eine Studie des Medienhaus Wien. Wien: Medienhaus.

Kepplinger, H. M., Brosius, H.-B., \& Staab, J. F. (1991). Instrumental actualization: A theory of mediated conflicts. European Journal of Communication, 6(3), 263-290.

Krüger, U. M., \& Müller-Sachse, K. H. (1998). Medienjournalismus. Strukturen, Themen, Spannungsfelder. Opladen: Westdeutscher Verlag.

Malik, M. (2004). Journalismusjournalismus. Funktionen, Strukturen und Stra- tegien der journalistischen Selbstthematisierung. Wiesbaden: VS.

Peters, H. P. (2008). Scientists as public experts. In M. Bucchi, \& B. Trench (Eds.), The handbook of public communication of science and technology (pp. 131-146). Routledge: London.

Peters, H. P., Heinrichs, H., Jung, A., Kallfass, M., \& Petersen, I. (2008). Medialization of science as a prerequisite of its legitimization and political relevance. In C. Donghong, et al. (Eds.), Communicating science in social contexts. News models, new practices (pp. 7192). Dordrecht: Springer.

Peters, H. P. (2012). Scientific Sources and the Mass Media: Forms and Consequences of Medialization. In S. Rödder, M. Franzen, \& P. Weingart (Eds.), The sciences' media connection - Public communication and its repercussions (pp. 217-239). Dordrecht: Springer.

Rademacher, L. (2011). Lautsprecher und Leisetreter. Braucht die Kommunikationswissenschaft mehr PR? Aviso, 53, 2-3.

Russ-Mohl, S. (1997, January 31). Die Debatte um die Kommunikationswissenschaft: Das Fach ist durchaus leistungsfähig. Die Zeit, 06, 65.

Saxer, U. (1997). Die prekäre Medienöffentlichkeit der Sozialwissenschaften. Relation, 4(1), 51-60.

Schäfer, M. S. (2009). From public understanding to public engagement. An empirical assessment of changes in science coverage. Science Communication, 34(4), 475-505.

Schäfer, M. S. (2011). Sources, characteristics and effects of mass media communication on science: A review of the literature, current trends and areas for future research. Sociology Compass, 5(6), 399-412.

Schäfer, M. S. (2012). Taking stock: a meta-analysis of studies on the media's 
coverage of science. Public Understanding of Science, 21(6), 650-663.

Silbermann, A. (1996, December 13). Abgesang auf die deutsche Medien- und Kommunikationswissenschaft. Marottenhafte Wichtigtuerei. Die Zeit, 51, 53.

Straub, C., \& Schönhagen, P. (2007):

Wandel nach der Krise? Tendenzen im Schweizer Medienjournalismus. Medienheft, 21. Mai 2007.

Weiss, C. H., \& Singer, E. (1988). Reporting of social science in the national media. New York: Russel Sage.

Weßler, H. (1997). Verschlungene Pfade. Wie sozialwissenschaftliches Wissen in die Medienberichterstattung einfließt. Relation, 4(1), 117-148.
Weingart, P. (2012). The lure of the mass media and its repercussions on science. Theoretical considerations on the 'medialization of science'. In S. Rödder, M. Franzen, \& P. Weingart (Eds.), The sciences' media connection - Public communication and its repercussions (pp. 17-32). Dordrecht: Springer.

Wormer, H. (2009). Science journalism. In W. Donsbach (Ed.), The international encyclopedia of communication, Blackwell Publishing. Retrieved from http:// www.communicationencyclopedia. com-/subscriber/tocnode? id= g9781405131995_yr2011_chunk_ g978140513199524_ss19-1.

Wyss, V. (2011, April 16). Kassandra lässt grüßen. Neue Zürcher Zeitung, 96, 44. 